\title{
Immuno-Double-Diffusion Serological Relationships Among Spiroplasma Isolates
}

\author{
UMARONY COOMARASWAMY ${ }^{1}$ AND D. J. GUMPF ${ }^{2 *}$ \\ Department of Botany, Balticaloa University, Vantherunoolai, Chenkaladi, Sri Lanka, ${ }^{1}$ and Department of Plant \\ Pathology, University of California, Riverside, California $92521^{2}$
}

\begin{abstract}
Spiroplasma citri strains Maroc R8A2 ${ }^{\mathrm{T}}$ ( $\mathrm{T}=$ type strain), C189, and C3B, corn stunt Spiroplasma sp. strain E275, and honeybee Spiroplasma sp. strain BC3 all cross-reacted in reciprocal serological tests when an agar double-diffusion system was used. These strains, which are members of Spiroplasma group I, did not show any cross-reactions with flower Spiroplasma strains BNR1 and PPS1, (Spiroplasma floricola and "Spiroplasma apis") or with the tick-derived organism Spiroplasma mirum. Tick Spiroplasma sp. strain $277 \mathrm{~F}$ and honeybee Spiroplasma sp. strain AS576 reacted only with antisera prepared against other members of group I. Group III flower spiroplasmas $S$. floricola $23-6^{\mathrm{T}}$ and BNR1 and group IV strains PPS1 and SR3 did not react with antisera prepared against isolates outside their own groups. The members of each major group showed close antigenic relatedness to each other but not to $S$. mirum strain $\mathrm{SMCA}^{\mathrm{T}}$, which showed minimal one-way cross-reactions with members of group I. Previous serogrouping results for the Spiroplasma strains tested were confirmed by the serological reactions of the organisms in the doublediffusion system.
\end{abstract}

The list of spiroplasmas that have been isolated and cultivated has become extensive enough to establish criteria that are useful for strain and species identification within the genus Spiroplasma. The following techniques can be used to characterize and compare the diverse isolates of Spiroplas$m a$ : serological methods, such as growth inhibition $(3,16$, 18-21, 23; R. E. Davis et al., Abstr. Annu. Meet. Am. Phytopathol. Soc. 1978, abstr. no. 415, p. 215; B. C. Raju and T.-A. Chen, Abstr. Div. Meet. Am. Phytopathol. Soc. 1977, abstr. no. NE-71, p. 195) and complement fixation (19); organism deformation $(16,23,25$; A. H. McIntosh et al., Abstr. Div. Meet. Am. Phytopathol. Soc. 1977, abstr. no. NE-57, p. 193; Raju and Chen, Abstr. Div. Meet. Am. Phytopathol. Soc. 1977); metabolic inhibition (3, 7; R. E. Davis, Abstr. Div. Meet. Am. Phytopathol. Soc. 1978, abstr. no. PO-7, Phytopathol. News, Vol. 12; Raju and Chen, Abstr. Div. Meet. Am. Phytopathol. Soc. 1977); ring interface precipitin tests (19; R. E. Davis et al., Abstr. Annu. Meet. Am. Phytopathol. Soc. 1978; Raju and Chen, Abstr. Div. Meet. Am. Phytopathol. Soc. 1977); and an enzymelinked immunosorbent assay (1). To our knowledge, immuno-double-diffusion has not been used as a technique to characterize and compare isolates of Spiroplasma. Within the genus Mycoplasma, it has been reported that some strains which are distinguishable by other serological methods appear to be closely related on the basis of immunodouble-diffusion tests $(11,12,17)$ and that these tests provide a means of clarifying the status of strains or variants of a given species $(8,12)$. Thus, the use of immuno-doublediffusion as a method for demonstrating group antigens might provide a means for serologically defining strains of Spiroplasma species.

The present study was undertaken (as part of a cooperative effort of the Spiroplasma Working Team of the International Research Programme of Comparative Mycoplasmology) to determine the antigenic relationships among 12 Spiroplasma strains by using immuno-double-diffusion tests to identify common or group antigens. The 12 strains were chosen to represent the four major Spiroplasma groups and

* Corresponding author. the subgroups of group I described by Davis et al. (7) and Williamson et al. (22). After this study was completed, revisions of the serological classification added several new groups (20; J. M. Bové et al., Yale J. Biol. Med., in press).

\section{MATERIALS AND METHODS}

Organisms. The Spiroplasma strains used in this study and the sources from which they were derived are shown in Table 1. Spiroplasma citri strains C3B, C189, and Maroc $\mathrm{R}^{2} 2^{\mathrm{T}}$ ( $\mathrm{T}=$ type strain) were from cloned cultures maintained in our laboratory. Cloned cultures of strains E275 (corn stunt strain), 277F (tick strain), and BC3 (honeybee strain), Spiroplasma floricola BNR1, "Spiroplasma apis", PPS1, and Spiroplasma mirum $\mathrm{SMCA}^{\mathrm{T}}$ (Georgia), were supplied by R. F. Whitcomb, Plant Protection Institute, U.S. Department of Agriculture, Beltsville, Md. Cultures of strain AS576, S. floricola $23-6^{\mathrm{T}}$, and strain SR3 were supplied by R. E. Davis, Plant Virus Laboratory, Plant Protection Institute, U.S. Department of Agriculture, Beltsville, Md.

Cultivation of organisms and preparation of antigens. All strains except strain $\mathrm{SMCA}^{\mathrm{T}}$ were propagated and maintained in M1A liquid medium (9). Strain SMCA ${ }^{\mathrm{T}}$ was propagated and maintained in SP-4 liquid medium (19).

To eliminate nonspecific cross-reactions in the diffusion tests resulting from serum antigens, the medium used for cultivation of the immunizing antigen was supplemented with Mycoplasma-free bovine serum (GIBCO Laboratories, Grand Island, N.Y.), whereas horse serum (GIBCO) was used for growing the serological test antigens. A 2-ml sample from a logarithmic growth phase culture was used as the inoculum for each $600 \mathrm{ml}$ of liquid medium. All cultures were incubated aerobically at 30 to $32^{\circ} \mathrm{C}$ until we observed a decrease in the $\mathrm{pH}$, as indicated by a color change in the medium from red to yellow. At this stage the cultures were centrifuged at $14,000 \times g$ for $20 \mathrm{~min}$ to sediment the organisms. The pelleted organisms were washed three times with phosphate-buffered saline and then suspended in 1/300 of the original culture volume of phosphate-buffered saline. The total protein contents of all preparations were measured by the procedure of Lowry et al. (13), using crystalline bovine albumin as the standard. For immunizing antigens, 
TABLE 1. Sources of strains of Spiroplasma species

\begin{tabular}{|c|c|c|c|c|}
\hline Taxon & Strain & Host origin & ATCC no. & Reference(s) \\
\hline S. citri & Maroc $\mathrm{R} 8 \mathrm{~A} 2^{\mathrm{T}}$ & Citrus (stubborn disease) & $27556^{\mathrm{T}}$ & 15 \\
\hline S. citri & C189 & Citrus (stubborn disease) & 27665 & \\
\hline S. citri & $\mathrm{C} 3 \mathrm{~B}$ & Circulifer tenellus & & $\mathrm{Lee}^{a}$ \\
\hline Spiroplasma sp. & $\mathrm{E} 275$ & Corn (stunt disease) & 28329 & 24 \\
\hline Spiroplasma sp. & $277 \mathrm{~F}$ & Rabbit tick & 29761 & 2 \\
\hline Spiroplasma sp. & $\mathrm{BC} 3$ & Honeybee & 33219 & 4 \\
\hline Spiroplasma sp. & AS576 & Honeybee & 29416 & 7 \\
\hline S. floricola & BNR1 & Tulip tree flowers & 33220 & 20 \\
\hline S. floricola & $23-6^{\mathrm{T}}$ & Tulip tree flowers & $29989^{\mathrm{T}}$ & 5 \\
\hline$" S$, apis" & PPS1 & Powderpuff flowers & 33450 & 14 \\
\hline Spiroplasma sp. & SR3 & Tulip tree flowers & 33095 & 5,6 \\
\hline S. mirum & $\mathrm{SMCA}^{\mathrm{T}}$ & Rabbit tick & $29335^{\mathrm{T}}$ & 19 \\
\hline
\end{tabular}

${ }^{a}$ I.-M. Lee, Ph.D. thesis, University of California, Riverside, 1977.

samples containing 15 to $25 \mathrm{mg}$ of total protein were placed in small vials and stored at $-60^{\circ} \mathrm{C}$ if they were not used immediately. Test antigens were divided into $1-\mathrm{ml}$ portions containing $40 \mathrm{mg}$ of total protein, lyophilized, and stored at $-60^{\circ} \mathrm{C}$ until they were used. To observe nonspecific reactions with the medium components, a control antigen was prepared from uninoculated M1A and SP-4 broth media processed in an identical manner.

Preparation of antisera. Antisera against $S$. citri strains $\mathrm{C} 3 \mathrm{~B}, \mathrm{C} 189$, and Maroc $\mathrm{R} 8 \mathrm{~A}^{\mathrm{T}}{ }^{\text {, }}$ corn stunt strain E275, honeybee strain BC3, flower strains BNR1 and PPS1, and the tick-derived organism $S$. mirum $\mathrm{SMCA}^{\mathrm{T}}$ were prepared in rabbits. Before immunizations were started, $5 \mathrm{ml}$ of preimmunization serum was collected from each rabbit. Immunizing antigens were prepared by mixing 1.0 to $1.5 \mathrm{ml}$ of antigen (15 to $25 \mathrm{mg}$ of protein) with an equal volume of Freund complete adjuvant. Each animal received four intramuscular injections at 10-day intervals. At 10 days after the fourth injection, each animal was test-bled for titer determinations. When the serum titer, as determined by microprecipitin tests and immunodiffusion tests, reached 1:1,024 or above, the animals were bled every 3 or 4 days until the titer declined. The antisera were divided into $1-\mathrm{ml}$ portions and stored at $-20^{\circ} \mathrm{C}$ until they were used.

Gel diffusion tests. Because many $S$. citri antigens seem to be associated with membranes (7), the methods used for disrupting the cells of this organism are important in the satisfactory preparation of a test antigen for immunodiffusion systems (7). Cells of $S$. citri were treated in various ways, including osmotic shock with distilled water, treatment with surface-active agents and solvents, such as Igepon T-73 (sodium $N$-methyl- $N$-oleoyltaurate), sodium dodecyl sulfate, Leonil SA (sodium dibutylnaphthalenesulfonate), Triton X-100, and polyvinylpyrollidone, alternate cycles of freezing and thawing, and ultrasonic disruption. The effects of these treatments were evaluated by immunodiffusion. Igepon T-73 added at a final concentration of $0.1 \%$ to the serological test antigen $10 \mathrm{~min}$ before use resulted in the greatest number of precipitin lines in our immunodiffusion system.

The serological test antigens used in this study were diluted so they had comparable protein contents. Based on preliminary studies, two dilutions of antigen ( 40 and $10 \mathrm{mg}$ of protein per $\mathrm{ml}$ ) and two dilutions of antiserum (undiluted and diluted 1:3) were used in the four possible combinations. One test consisted of five replicates for each of the four combinations. All tests were repeated three times, with similar results. The tests were performed on immunodiffusion microslides containing an agar gel supplemented with
$0.1 \%$ (wt/vol) sodium azide (Hyland Diagnostics, Bannockburn, III.). Each slide had three sets of wells, and each set comprised a central well and five peripheral wells that were 2 $\mathrm{mm}$ in diameter. The distance between the centers of the central well and the peripheral wells was $7 \mathrm{~mm}$. The antigen wells were filled with $20 \mu \mathrm{l}$ of antigen, and the slides were incubated at room temperature in a humid chamber for 2 to 5 days.

\section{RESULTS}

The pre-immunization rabbit sera did not react with antigens prepared in agamma horse serum, whereas the hyperimmune sera produced precipitation lines with the homologous antigens but not with concentrates of uninoculated broth media (control antigen). The antigens of 12 Spiroplas$m a$ strains were cross-tested with antisera against 8 of these strains (Table 2). As a result of these studies, the Spiroplas$m a$ strains listed in Table 2 were placed in the groups and subgroups that were proposed by Davis et al. (7) and Junca et al. (10) and later revised by Whitcomb et al. (20).

One example of the relationships among the Spiroplasma strains is illustrated in Fig. 1. Antiserum prepared against $S$. citri $\mathrm{C} 189$ formed three precipitation lines, designated lines a, b, and d (Fig. 1, wells 1, 4, 6, and 9), with the homologous antigen. At least one of the precipitation lines (line a) produced by the strain $\mathrm{C} 189$ antiserum and its homologous antigen fused with a corresponding line formed with $S$. citri Maroc R8A2 ${ }^{\mathrm{T}}$ and $\mathrm{C} 3 \mathrm{~B}$ and Spiroplasma sp. strains E275, $277 \mathrm{~F}, \mathrm{BC} 3$, and AS576, indicating that there was at least one identical antigenic component among these strains. The strains Maroc $\mathrm{R} 8 \mathrm{~A} 2^{\mathrm{T}}$ and $\mathrm{C} 3 \mathrm{~B}$ shared another common antigen (precipitin line $b$ ), which also fused with the corresponding line in the homologous reaction (Fig. 1, wells 1, 2, 4 , and 5). In addition to this common antigen, a line corresponding to line $b$ of the homologous reaction was also produced by the strain $\mathrm{C} 189$ antiserum and the antigens of strains E275, BC3, and 277F. These precipitin lines formed spurs at the junctions of the homologous reactions (Fig. 1, wells 2,7 , and 10 ), indicating that they are related to precipitin line $b$ of the homologous systems but not identical. All strains except strains Maroc $\mathrm{R} 8 \mathrm{~A} 2^{\mathrm{T}}$ and $\mathrm{C} 3 \mathrm{~B}$ lacked precipitin line $c$. Furthermore, both strain C189 and strain $\mathrm{C} 3 \mathrm{~B}$ showed one additional line (designated line $\mathrm{d}$ for strain C189 and line e for strain C3B) (Fig. 1, wells 1 and 2). The strain PPS1, SR3, BNR1, 23-6 ${ }^{\mathrm{T}}$, and $\mathrm{SMCA}^{\mathrm{T}}$ antigens did not show any precipitation lines, suggesting that they did not have any antigenic components which were identical or related to strain $\mathrm{C} 189$ components. 
TABLE 2. Comparison of 12 Spiroplasma isolates by double immunodiffusion tests

\begin{tabular}{|c|c|c|c|c|c|c|c|c|c|c|}
\hline \multirow[b]{2}{*}{ Group } & \multirow[b]{2}{*}{$\begin{array}{l}\text { Sub- } \\
\text { group }\end{array}$} & \multirow[b]{2}{*}{ Antigen from: } & \multicolumn{8}{|c|}{ No. of precipitin lines with antiserum from strain: } \\
\hline & & & $\begin{array}{l}\text { Maroc } \\
\text { R8A2 }^{\mathrm{T}}\end{array}$ & C189 & $\mathrm{C} 3 \mathrm{~B}$ & E275 & $\mathrm{BC} 3$ & BNR1 & PPS 1 & $\mathrm{SMCA}^{\mathrm{T}}$ \\
\hline \multirow[t]{7}{*}{ I } & 1 & S. citri Maroc $\mathrm{R} 8 \mathrm{~A} 2^{\mathrm{T}}$ & $3(\mathrm{a}, \mathrm{b}, \mathrm{c})^{a, b}$ & $3(a, b, c)$ & $3(a, b, c)$ & 1 (a) & $2(a, d-p)$ & 0 & 0 & 1 (a) \\
\hline & 1 & S. citri $\mathrm{C} 189$ & $3(a, b, d)$ & $3(\mathrm{a}, \mathrm{b}, \mathrm{d})^{b}$ & $3(a, b, d)$ & 1 (a) & $3(a, b, d-p)$ & 0 & 0 & 1 (a) \\
\hline & 1 & S. citri C3B & $4(\mathrm{a}, \mathrm{b}, \mathrm{c}, \mathrm{e})$ & $4(\mathrm{a}, \mathrm{b}, \mathrm{c}, \mathrm{e})$ & $3(\mathrm{a}, \mathrm{b}, \mathrm{c})^{b}$ & 1 (a) & $3(a, b, d-p)$ & 0 & 0 & 1 (a) \\
\hline & 2 & Honey bee strain $\mathrm{BC} 3$ & $2(a, b-p)$ & $2(b-p)$ & 1 (b-p) & 1 (a) & $4(\mathrm{a}, \mathrm{b}, \mathrm{d}, \mathrm{h})^{b}$ & 0 & 0 & 1 (a) \\
\hline & & Honey bee strain AS576 & 1 (a) & 1 (a) & 0 & 0 & $2(a, b-p)$ & 0 & 0 & 1 (a) \\
\hline & 3 & Corn stunt strain E275 & $2(a, b-p)$ & $2(a, b-p)$ & $2(a, b-p)$ & $2(\mathrm{a}, \mathrm{f}, \mathrm{g})^{b}$ & $2(a, d-p)$ & 0 & 0 & 1 (a) \\
\hline & 4 & Tick strain $277 \mathrm{~F}$ & $2(a, b-p)$ & $2(a, b-p)$ & $1(b-p)$ & 1 (a) & 0 & 0 & 0 & 1 (a) \\
\hline \multirow[t]{2}{*}{ III } & & S. floricola BNR1 & 0 & 0 & 0 & 0 & 0 & $3(\mathrm{i}, \mathrm{j}, \mathrm{k})^{b}$ & 0 & 0 \\
\hline & & S. floricola $23-6^{\mathrm{T}}$ & 0 & 0 & 0 & 0 & 0 & $2(\mathrm{i}, \mathrm{j})$ & 0 & 0 \\
\hline \multirow{2}{*}{ IV } & & Strain PPS1 & 0 & 0 & 0 & 0 & 0 & 0 & $2(1, \mathrm{~m})^{b}$ & 0 \\
\hline & & Strain SR3 & 0 & 0 & 0 & 0 & 0 & 0 & $1(1)$ & 0 \\
\hline V & & S. mirum $\mathrm{SMCA}^{\mathrm{T}}$ & 0 & 0 & 0 & 0 & 0 & 0 & 0 & $3(\mathrm{~m}, \mathrm{n}, \mathrm{o})^{b}$ \\
\hline
\end{tabular}

${ }^{a}$ The letters in parentheses are precipitin line designations; the suffix -p indicates partial identity (spurred precipitin lines).

${ }^{b}$ Homologous reaction.

The results of our tests can be summarized as follows: (i) strains Maroc R8A2 ${ }^{\mathrm{T}}, \mathrm{C} 189$, and $\mathrm{C} 3 \mathrm{~B}$ share at least two common antigenic components; (ii) strains Maroc $\mathrm{R} 8 \mathrm{~A} 2^{\mathrm{T}}$ and $\mathrm{C} 3 \mathrm{~B}$ share three common antigenic components; (iii) at least one antigenic component is common to strains Maroc $\mathrm{R} 8 \mathrm{~A} 2^{\mathrm{T}}, \mathrm{C} 189, \mathrm{C} 3 \mathrm{~B}, \mathrm{E} 275, \mathrm{BC} 3$, and AS576; (iv) strains Maroc R8A2 ${ }^{\mathrm{T}}, \mathrm{C} 189, \mathrm{C} 3 \mathrm{~B}, \mathrm{E} 275,277 \mathrm{~F}$, and BC3 have an additional partially related component; (v) strains BNR1, 23$6^{\mathrm{T}}, \mathrm{PPS} 1$ and SR3 are antigenically distinct from the strains mentioned above; and (vi) antiserum prepared against strain SMCA $^{\mathrm{T}}$ contained antibodies to one antigenic component of strains Maroc R8A2 ${ }^{\mathrm{T}}, \mathrm{C} 189, \mathrm{C} 3 \mathrm{~B}, \mathrm{E} 275,277 \mathrm{~F}, \mathrm{BC} 3$, and
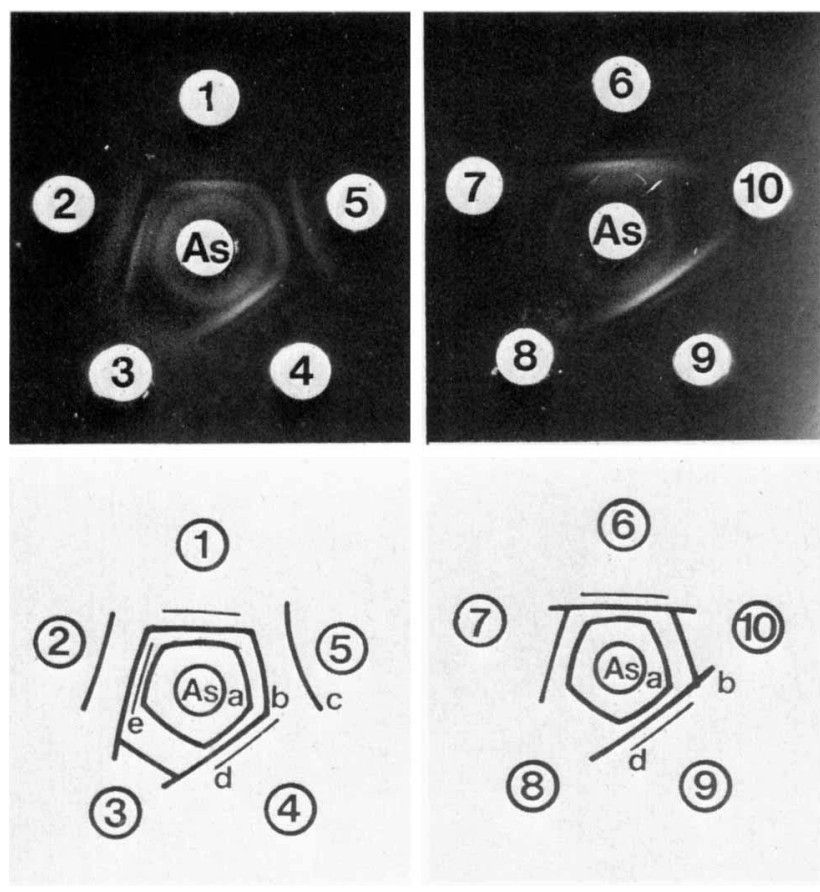

FIG. 1. Photographs and line drawings of immuno-double-diffusion plates showing serological relationships among seven of the isolates tested. Well As, $S$. citri $\mathrm{C} 189$ antiserum; well $1, S$. citri C189; well 2, S. citri C3B; well 3, Spiroplasma sp. strain E275; well 4, S. citri C189; well 5, S. citri Maroc $\mathrm{R}^{\mathrm{AA}} 2^{\mathrm{T}}$; well $6, S$. citri $\mathrm{C} 189$; well 7 , Spiroplasma sp. strain BC3; well 8 , Spiroplasma sp. strain AS576; well 9, S. citri C189; well 10, Spiroplasma sp. strain 277F.
AS576, but the reciprocal tests did not produce in similar reactions.

\section{DISCUSSION}

The data in Table 2 show very clear antigenic relationships among $S$. citri strains Maroc $\mathrm{R} 8 \mathrm{~A} 2^{\mathrm{T}}, \mathrm{C} 189$, and C3B and, to a lesser extent, relationships with the other strains in group I (strains BC3, AS576, E275, and 277F). The Spiroplasma strains in groups III and IV showed no cross-reactions with the strains belonging to other groups. $S$. mirum $\mathrm{SMCA}^{\mathrm{T}}$, the only member of group $\mathrm{V}$ tested, did not show any crossreactions with the strains in groups III and IV. However, it did have one common antigen with the group I strains. This common component was present in very low concentrations, because no precipitation line formed after antigen or antiserum dilution. This low-level one-way reaction may confirm previous reports that indicated a possible antigenic relationship between $S$. mirum $\mathrm{SMCA}^{\mathrm{T}}$ and the corn stunt strain (18, 19). The one-way cross-reactions between the honeybee strains and antiserum to strain BNR1 that were revealed by metabolic inhibition and deformation tests (22) were not evident in this study. This is not surprising since the results of immuno-double-diffusion identification of mycoplasmas often differ from the results obtained by other methods (11, $12,17)$.

Although common antigenic components among all strains of the same major group were not found with the techniques used in this study, they may exist but may not be recognized immunologically by rabbits, or they may be present in low concentrations and not detected by our assays. Despite our inability to demonstrate similar strong common antigens, the consistent presence of reciprocal cross-reactions among group I strains suggests that at least some members of this group possess common antigens which may be regarded as group antigens.

\section{ACKNOWLEDGMENTS}

We thank the American Council on Education and the Council for International Exchange of Scholars for providing one of us (U.C.) with a Mutual Educational Exchange Grant under the Fulbright Programs. This study was funded in part by the California Citrus Advisory Board.

\section{LITERATURE CITED}

1. Bové, J. M., and C. Saillard. 1979. Cell biology of spiroplasmas, p. 83-153. In R. F. Whitcomb and J. G. Tully (ed.), The 
mycoplasmas: plant and insect mycoplasmas, vol. 3. Academic Press, Inc., New York.

2. Brinton, L. P., and W. Burgdorfer. 1976. Cellular and subcellular organization of the $277 \mathrm{~F}$ agent: a spiroplasma from the rabbit tick Haemaphysalis leporispalustris (Acari: Ixodidae). Int. J. Syst. Bacteriol. 26:544-560.

3. Chen, T. A., and C. H. Liao. 1975. Corn stunt spiroplasma: isolation, cultivation and proof of pathogenicity. Science 188:1015-1016.

4. Clark, T. B. 1977. Spiroplasma sp., a new pathogen in honey bees. J. Invertebr. Pathol. 29:112-113.

5. Davis, R. E. 1978. Spiroplasma associated with flowers of the tulip tree (Liriodendron tulipifera L.). Can. J. Microbiol. 24:954-959.

6. Davis, R. E., and I. M. Lee. 1982. Comparative properties of spiroplasmas and emerging taxonomic concepts: a proposal. Rev. Infect. Dis. 4:S122-S128.

7. Davis, R. E., I. M. Lee, and L. K. Basciano. 1979. Spiroplasmas: serological grouping of strains associated with plants and insects. Can. J. Microbiol. 25:861-866.

8. Deeb, B. J., and G. E. Kenny. 1967. Characterization of $M y c o-$ plasma pulmonis variants isolated from rabbits. II. Basis for differentiation of antigenic sub-types. J. Bacteriol. 93:14251429 .

9. Jones, A. L., R. F. Whitcomb, D. L. Williamson, and M. E. Coan. 1977. Comparative growth and primary isolation of spiroplasma in media based on insect tissue culture formulations. Phytopathology 67:738-746.

10. Junca, P., C. Saillard, J. Tully, O. Garcia-Jurado, J. R. Degorce-Dumas, C. Mouches, J. C. Vignault, R. Vogel, R. McCoy, R. Whitcomb, D. Williamson, J. Latrille, and J. M. Bové. 1980. Caractérisation de spiroplasmes isoles d'insectes et de fleurs de France continentale, de corse et du Maroc: proposition pour une classification des spiroplasmes. C. R. Acad. Sci. Ser. D 290:1209-1212.

11. Kenny, G. E. 1969. Serological comparison of ten glycolytic Mycoplasma species. J. Bacteriol. 98:1044-1055.

12. Lemcke, R. M. 1965. A serological comparison of various species of Mycoplasma by agar gel-double diffusion technique. J. Gen. Microbiol. 38:91-100.

13. Lowry, O. H., N. J. Rosebrough, A. L. Farr, and R. J. Randall. 1951. Protein measurement with the Folin phenol reagent. J. Biol. Chem. 193:265-275.

14. McCoy, R. E., D. S. Williams, and D. L. Thomas. 1979. Isola- tion of mycoplasmas from flowers, p. 75-80. In H. J. Su and R. E. McCoy (ed.), Proceedings of the United States-Republic of China Cooperative Science Seminar, Mycoplasma Diseases of Plants. National Science Council Symposium Series no. 1. National Science Council, Taipai.

15. Saglio, P., M. L'Hospital, D. Lafleche, G. Dupont, J. M. Bové, J. G. Tully, and E. A. Freundt. 1973. Spiroplasma citrigen. and sp. n.: a mycoplasma-like organism associated with "stubborn" disease of citrus. Int. J. Syst. Bacteriol. 23:191-204.

16. Stalheim, O. H. V., A. E. Ritchie, and R. F. Whitcomb. 1978. Cultivation, serology, ultrastructure and virus-like particles of spiroplasma 277F. Curr. Microbiol. 1:365-370.

17. Taylor-Robinson, D., N. L. Somerson, H. C. Turner, and R. M. Chanock. 1963. Serological relationships among human mycoplasmas as shown by complement fixation and gel diffusion. J. Bacteriol. 85:1261-1273.

18. Tully, J. G., R. F. Whitcomb, J. M. Bové, and P. Saglio. 1973 Plant mycoplasmas: serological relation between agents associated with citrus stubborn and corn stunt diseases. Science 182:827-829.

19. Tully, J. G., R. F. Whitcomb, H. F. Clark, and D. L. Williamson. 1977. Pathogenic mycoplasmas: cultivation and vertebrate pathogenicity of a new spiroplasma. Science 195:892-894.

20. Whitcomb, R. F., J. G. Tully, T. B. Clark, D. L. Williamson, and J. M. Bové. 1982. Revised serological classification of spiroplasmas, new provisional groups, and recommendations for serotyping of isolates. Curr. Microbiol. 7:291-296.

21. Whitcomb, R. F., J. G. Tully, P. McCawley, and D. L. Rose. 1982. Application of the growth inhibition test to Spiroplasma taxonomy. Int. J. Syst. Bacteriol. 32:387-394.

22. Williamson, D. L., J. G. Tully, and R. F. Whitcomb. 1979 Serological relationships of spiroplasmas as shown by combined deformation and metabolism inhibition tests. Int. J. Syst. Bacteriol. 29:345-351.

23. Williamson, D. L., and R. F. Whitcomb. 1974. Helical, wall-free prokaryotes in Drosophila, leafhoppers, and plants. Colloq. Inst. Natl. Sante Rech. Med. 33:283-290.

24. Williamson, D. L., and R. F. Whitcomb. 1975. Plant mycoplasmas: a cultivable spiroplasma causes corn stunt disease. Science 188:1018-1020

25. Williamson, D. L., R. F. Whitcomb, and J. G. Tully. 1978. The spiroplasma deformation test, a new serological method. Curr. Microbiol. 1:203-207. 